\title{
Sodium nitroprusside: low price and safe drug to control BP during thrombolysis in AIS
}

\author{
Nitroprussiato de sódio: uma droga segura e de baixo custo para o controle de PA durante \\ a trombólise em AVC isquêmico
}

Jessyca L. Koslyk, Renata D. Ducci, Edison M. Nóvak, Viviane F. Zétola, Marcos C. Lange

\begin{abstract}
This study analyzes the use of sodium nitroprusside (SN) as an option to reduce blood pressure (BP) below 180/105 mmHg during the management of acute ischemic stroke (AIS) in patients submitted to intravenous thrombolysis. Method: The sample was composed by 60 patients who had AIS and were submitted to intravenous rtPA, split in two groups: half in the control group (CG) with BP $<180 / 105 \mathrm{mmHg}$ and half in SN group with BP > 180/105 mmHg. Outcome variables were any hemorrhagic transformation (HT); the presence of symptomatic HT, National Institute of Health Stroke Scale (NIHSS) after 24 hours of treatment; the independence on discharge and death until three months after stroke onset. Results: There were no statistical differences between both groups to any of the outcome variables analyzed. Conclusion: The SN might be safe for BP control during thrombolysis to AIS.
\end{abstract}

Keywords: ischemic stroke, thrombolytic therapy, hypertension, sodium nitroprussite, safety.

\section{RESUMO}

Este estudo analisa o uso de nitroprussiato de sódio (NS) como uma opção para reduzir a pressão arterial (PA) durante o tratamento do AVC isquêmico agudo (AVCi) em pacientes submetidos à trombólise intravenosa (rtPA). Método: A amostra foi composta por 60 pacientes que tiveram AVCi e foram submetidos a rtPA, dividida em dois grupos: 30 pacientes no grupo controle (GC), com PA < 180/105 mmHg e 30 pacientes no grupo NS com PA > 180/105 mmHg. As variáveis analisadas foram qualquer transformação hemorrágica (TH); a presença de TH sintomática, NIHSS após 24 horas de tratamento; a independência na alta e morte até três meses após o AVCi. Resultados: Não houve diferença estatística entre os dois grupos para qualquer das variáveis de desfecho analisadas. Conclusão: 0 NS pode ser seguro para o controle da pressão arterial durante a trombólise no AVCi.

Palavras-chave: AVC isquêmico, terapia trombolítica, hipertensão, nitroprussiato de sódio, segurança.

The blood pressure (BP) control is an important goal in the management of the acute ischemic stroke (AIS). Current guidelines suggest that BP must be maintained bellow 180/105 mmHg when recombinant tissue plasminogen activator (rtPA) is used ${ }^{1,2}$. There are large numbers of drugs to control BP in this setting, but in the public Health Brazilian System, beside the continuous improving in the assistance of AIS, the intravenous medications available are metoprolol and sodium nitroprusside ${ }^{2}$.

Sodium nitroprusside (SN) was previously related to intracranial hypertension, rebound effect and BP control liability $^{3}$. On the other way, $\mathrm{SN}$ is a low price, spread in all country and could improve the blood flow in ischemic region ${ }^{4}$.

The aim of the study is to analyze if the use of SN to BP control is safe in patients with AIS submitted to intravenous rtPA.

\section{METHOD}

A case-control study where 60 patients composed the sample, all them had ischemic stroke (IS) and were submitted to intravenous rtPA between July 2010 and December 2011 in the Hospital de Clinicas from the Federal University of Parana in Curitiba (HC-UFPR), Brazil. Patients were selected from the Stroke Data Bank of the Neurology Division from the HC-UFPR. They were retrospectively selected and pared by age, gender and admission National Institute of Health Stroke Scale (NIHSS) in two groups: Thirty patients in the Control Group (CG) with BP levels below 180/105 mmHg, without requiring intravenous antihypertensive drug to control the BP previous or during the rtPA infusion. Thirty patients in SN Group (SNG) with BP levels over 180/105 mmHg requiring

Universidade Federal do Paraná, Hospital de Clínicas, Serviço de Neurologia, Curitiba PR, Brazil.

Correspondence: Marcos C Lange; Hospital de Clínicas, Serviço de Neurologia; Rua General Carneiro, 181/4º andar; 80060-900 Curitiba PR, Brasil;

E-mail: langeneuro@gmail.com

Conflict of interest: There is no conflict of interest to declare.

Received 12 December 2014; Received in final form 10 April 2015; Accepted 30 April 2015. 
SN to control the BP. The BP considered was the high value before rtPA infusion. The BP control in SNG was based on the current Brazilian guidelines ${ }^{2}$. All patients were submitted to intravenous rtPA only if the BP was in control and bellow 180/105 mmHg with or without treatment. Exclusion criteria to this study were: 1) symptoms-to-needle longer than 4.5 hours; 2) bridge therapy (intra-arterial or mechanical); 3) interruption of rtPA treatment; 4) introduction of other BP treatment during rtPA infusion. In the period of study, four patients were not treated with rtPA because of uncontrolled $\mathrm{BP}$ and only one had his treatment interrupted because of BP control. The Hospital ethics committee authorized this study.

A certified neurologist in NIHSS examination evaluated all patients, and eligibility to thrombolysis in both groups was individually determined based on the inclusion and exclusion criteria described in the National Institute of Neurological Disorders and Stroke (NINDS), European Cooperative Acute Stroke Study (ECASS III) and current guidelines ${ }^{1,2,5,6}$.

Outcome variables were: 1) the presence of any hemorrhagic transformation (HT) between 24 and 36 hours after rtPA infusion characterized by hemorrhagic infarction (small petechiae or more confluent petechiae) and parenchymal hemorrhage (hematoma involved less than $30 \%$ of the infarcted area or involved at least $30 \%$ of the infarcted area or a clot was detected at some distance from the infarcted area $)^{7,8} ; 2$ ) the presence of symptomatic HT (SHT) between 24 and 36 hours after rtPA infusion considering NIHSS and brain $\mathrm{CT}$, characterized by brain imaging evidence of HT with clinical worsening, indicated by an NIHSS score increase of at least four points in the next 36 hours compared with the lower punctuation ${ }^{8}$; 3) NIHSS after 24 hours of treatment; 4) the independence on discharge, considering modified Rankin score $(\mathrm{mRS}) \leq 2 ; 5)$ death until three months after stroke onset. The late mRS was not evaluated in the present study, because most patients did not have the follow-up in the out-patient clinic of the hospital and the data were analyzed form the Stroke Data Bank of the Neurology Division, that included only admitted patients.

Statistical analyzes were performed with Statistica 8.0 software. Statistical significance was assessed by Student's t-test or the Mann Whitney test for continuous variables and the chi-squared test or Fisher's exact test for categorical variables. Statistical significance was set at $\mathrm{p}<0.005$.

\section{RESULTS}

The demographic and admission variables comparing both groups are presented in Table 1. There was no statistical difference between groups comparing risk factors, except by hypercholesterolemia that was more frequent in CG $(86.7 \%$ vs. $60 \%, \mathrm{p}=0.020$ ) and admission systolic and diastolic BP (in $\mathrm{mmHg}$ ), both were higher in SNG (systolic BP: $191.6 \pm 15.7$ vs. $149.4 \pm 20.5$, p < 0.001; diastolic BP: $111.9 \pm 17.9$ vs. $87.6 \pm 10.1$, $\mathrm{p}<0.001)$. Only two $(6.7 \%)$ patients in CG had BP levels below $120 / 80 \mathrm{mmHg}$ and five (16.7\%) patients in SNG presented with BP over 220/120 mmHg. There were no statistical differences between both groups to any of the outcome variables analyzed (Table 2).

\section{DISCUSSION}

The current case-control study demonstrated that the use of SN to BP control is safe in patients submitted to intravenous rtPA in AIS and did not change the outcome.

Table 1. Demographic and admission variables comparing SNG and CG.

\begin{tabular}{|c|c|c|c|}
\hline & $C G(n=30)$ & SNG $(n=30)$ & $p$-value \\
\hline Age in years (mean $\pm S D)$ & $67.7 \pm 10.8$ & $68.3 \pm 11.2$ & 0.833 \\
\hline Female gender, n (\%) & $13(43.33)$ & $13(43.3)$ & 1.000 \\
\hline NIHSS on admission (mean \pm SD) & $13.7 \pm 6.3$ & $13.6 \pm 6.2$ & 0.982 \\
\hline Hypertension, n (\%) & $23(76.67)$ & $27(90)$ & 0.166 \\
\hline Diabetes, n (\%) & $4(13.33)$ & $6(20)$ & 0.488 \\
\hline Previous coronary heart disease, n (\%) & $6(20)$ & $3(10)$ & 0.278 \\
\hline Hypercholesterolemia, n (\%) & $26(86.67)$ & $18(60)$ & 0.020 \\
\hline Current smoking, n (\%) & $6(20)$ & $10(33.33)$ & 0.243 \\
\hline Previous stroke, n (\%) & $4(13.33)$ & $6(20)$ & 0.488 \\
\hline Atrial fibrillation, n (\%) & $6(20)$ & $13(43.33)$ & 0.052 \\
\hline Cardiac heart failure, n (\%) & $6(20)$ & $5(16.67)$ & 0.739 \\
\hline Antiplatelet treatment, n (\%) & $10(33.33)$ & $13(43.33)$ & 0.426 \\
\hline Statin treatment, $\mathrm{n}(\%)$ & $6(20)$ & $7(23.33)$ & 0.754 \\
\hline Symptom-to-needle treatment in minutes (mean \pm SD) & $170.9 \pm 56.6$ & $191.7 \pm 52.9$ & 0.147 \\
\hline Systolic blood pressure in mmHg (mean \pm SD) & $149.4 \pm 20.5$ & $191.6 \pm 15.7$ & $<0.001$ \\
\hline Diastolic blood pressure in mmHg (mean \pm SD) & $87.6 \pm 10.1$ & $111.9 \pm 17.9$ & $<0.001$ \\
\hline Glicemic blood levels in mg/dL (mean \pm SD) & $112.6 \pm 34.7$ & $127.6 \pm 32.8$ & 0.091 \\
\hline Creatinine blood levels in mg/dL (mean \pm SD) & $0.95 \pm 0.40$ & $0.90 \pm 0.41$ & 0.542 \\
\hline
\end{tabular}

CG: Control Group; SNG: Sodium Nitroprusside Group; NIHSS: National Institute of Health Stroke Scale; SD: standard deviation. 
Table 2. Outcome variables comparing SNG and CG.

\begin{tabular}{lccc} 
& CG $(n=30)$ & NSG $(n=30)$ & $p$-value \\
\hline Hemorrhagic transformation, $n(\%)$ & $3(10)$ & $7(23.33)$ & 0.299 \\
Symptomatic hemorrhagic transformation, $n(\%)$ & $2(6.67)$ & $2(6.67)$ & 1.000 \\
NIHSS after 24 hours (mean \pm SD) & $7.96 \pm 7.01$ & $9.69 \pm 6.63$ & 0.276 \\
mRS $\leq$ 2 on discharge, $n$ (\%) & $12(42.86)$ & $10(37.04)$ & 0.785 \\
Mortality in the first three months, $n(\%)$ & $2(6.67)$ & $3(10)$ & 1.000 \\
\hline
\end{tabular}

CG: Control Group; NSG: Sodium Nitroprusside Group; NIHSS: National Institute of Health Stroke Scale; mRS: modified Rankin Score.

Patients with BP higher than the current limits to rtPA represent almost $27 \%$ of all AIS, and they do not have to be excluded only for the high $\mathrm{BP}^{9}$. The control of $\mathrm{BP}$ before thrombolysis as done in the current study is safe and permits a good outcome for these patients, similar to previous large studies with rtPA ${ }^{5,6,10}$.

A recent trial in acute hemorrhagic stroke patients demonstrated that $\mathrm{BP}$ reduction is safe ${ }^{11}$, and this was also observed in the China Antihypertensive Trial in Acute Ischemic Stroke (CATIS), were AIS patients ( first 48 hours of symptoms onset) submitted to reduction of BP did not have increase of their mortality and major disability in the first 14 days, but the they did not evaluated patients submitted to $\mathrm{rtPA}^{12}$. Another trial is ongoing and will help to answer if reduction of BP is safe in patients submitted to thrombolysis ${ }^{13}$. A main concern in decline BP in AIS is the higher risk of territory infarction because the cerebral autoregulation could be lost, and the maintenance of adequate BP levels could prevent the enlargement of ischemic lesion ${ }^{14}$.

SN is a predominantly direct venous dilatator, fast action and could change platelet function and regional cerebral blood flow ${ }^{15}$. Beside this, SN is a nitric oxid donor, an important substance to maintaining basal cerebral blood flow ${ }^{14,15,16}$. A previous study demonstrated that SN is safe and potentially effective treatment for established delayed cerebral vasoconstriction after aneurysmal subarachnoid hemorrhage for its mechanism of nitric oxid donor ${ }^{17}$. In the present study few patients had extremely high or low BP in both groups, and this could explain the current results. Previous studies demonstrated that the presence of abnormal (high or low) BP increases the chance for SHT, bad outcome and mortality $^{9,18,19,20}$. The main safety of rtPA in AIS is the presence of SHT, this was observed in 1.7 to $6.4 \%$ of patients in previous large studies ${ }^{5,6,10}$. In the current study, there was no difference in the frequency of SHT between both groups, but the small sample could reduce the probability to find any difference between groups for this variable.

This study has limitations since it is a small sample, single-center, retrospective case-control study whose patients were selected only if the following conditions were met: 1 ) received the full intravenous rtPA dosage and 2) were treated with SN before the introduction of thrombolysis. The current study does not take into account patients in which the rtPA infusion had to be stopped because no BP control had been achieved. The current study was based on a data bank analysis without information of BP during and after rtPA. The stratification of patients done according to BP measurements taken during the following 24 hours and also the total volume of SN infused could help identify outliers patients whose prognosis could turn out to be different than the results found by this investigation.

The SN might be safe in the BP control in patients with acute ischemic stroke candidates for thrombolytic therapy. The current results have to be considered in the future international guidelines because $\mathrm{SN}$ is a low cost medication and available in all world. Large trials could help us to understand better which patients are good responders to this treatment.

\section{References}

1. Jauch EC, Saver JL, Adams HPJr, Bruno A, Connors JJ, Demaerschalk BM et al. Guidelines for the early management of patients with acute ischemic stroke: a guideline for healthcare professionals from the American Heart Association/American Stroke Association. Stroke. 2013;44(3):870-947. doi:10.1161/STR.0b013e318284056a

2. Martins SC, Freitas GR, Pontes-Neto OM, Pieri A, Moro CH, Jesus PA et al. Guidelines for acute ischemic stroke treatment: part II: stroke treatment. Arq Neuropsiquiatr. 2012;70(11):885-93. doi:10.1590/S0004-282X2012001100012

3. Anile C, Zanghi F, Bracali A, Maira G, Rossi GF. Sodium nitroprusside and intracranial pressure. Acta Neurochir (Wien). 1981;58(3-4):203-11. doi:10.1007/BF01407126

4. Butterworth RJ, Cluckie A, Jackson SH, Buxton-Thomas M, Bath PM. Pathophysiological assessment of nitric oxide (given as sodium nitroprusside) in acute ischaemic stroke. Cerebrovasc Dis. 1998;8(3):158-65. doi:10.1159/000015842

5. Hacke W, Kaste M, Bluhmki E, Brozman M, Dávalos A, Guidetti $D$ et al. Thrombolysis with alteplase 3 to 4.5 hours after acute ischemic stroke. N Engl J Med. 2008;359(13):1317-29. doi:10.1056/NEJMoa0804656

6. The National Institute of Neurological Disorders and Stroke rt-PA Stroke Study Group. Tissue plasminogen activator for acute ischemic stroke. N Engl J Med. 1995;333:1581-8. doi:10.1056/NEJM199512143332401

7. Larrue V, Kummer R, Zoppo G, Bluhmki E. Hemorrhagic transformation in acute ischemic stroke. Potential contributing factors in the European Cooperative Acute Stroke Study. Stroke. 1997;28(5):957-60. doi:10.1161/01.STR.28.5.957 
8. Hacke W, Kaste M, Fieschi C, Toni D, Lesaffre E, Kummer R et al. Intravenous thrombolysis with recombinant tissue plasminogen activator for acute hemispheric stroke. JAMA. 1995;274(13):1017-25. doi:10.1001/jama.1995.03530130023023

9. Leonardi-Bee J, Bath PM, Phillips SJ, Sandercock PA. Blood pressure and clinical outcomes in the International Stroke Trial. Stroke. 2002;33(5):1315-20. doi:10.1161/01.STR.0000014509.11540.66

10. Wahlgren N, Ahmed N, Dávalos A, Ford GA, Grond M, Hacke W et al. Thrombolysis with alteplase for acute ischaemic stroke in the Safe Implementation of Thrombolysis in Stroke-Monitoring Study (SITS-MOST): an observational study. Lancet. 2007;369(9558):275-82. doi:10.1016/S0140-6736(07)60149-4

11. Anderson CS, Huang Y, Wang JG, Arima H, Neal B, Peng

$B$ et al. Intensive blood pressure reduction in acute cerebral haemorrhage trial (INTERACT): a randomised pilot trial. Lancet Neurol. 2008;7(5):391-9. doi:10.1016/S1474-4422(08)70069-3

12. He J, Zhang Y, Xu T, Zhao Q, Wang D, Chen CS et al. Effects of immediate blood pressure reduction on death and major disability in patients with acute ischemic stroke: the CATIS randomized clinical trial. JAMA. 2014;311(5):479-89. doi:10.1001/jama.2013.282543

13. The George Institure.. Enhanced Control of Hypertension and Thrombolysis Stroke Study (ENCHANTED). 2015 (cited 2015 Jan 15). Avaliable from: https://clinicaltrials.gov/ct2/show/NCT01422616?ter $\mathrm{m}=$ enchanted+stroke\&rank $=1$

14. Markus HS. Cerebral perfusion and stroke.J Neurol Neurosurg Psychiatry. 2004;75(3):353-61. doi:10.1136/jnnp.2003.025825
15. Hoffman BB. Terapia da hipertensão. In: Brunton LL, Lazo JS, Parker KL, editors. Goodman and Gilman's As bases farmacológicas da terapêutica. 6. ed. Rio de Janeiro: McGraw-Hill; 2006. p. 773-5.

16. White RP, Hindley C, Bloomfield PM, Cunningham VJ, Vallance $P$, Brooks DJ. The effect of the nitric oxide synthase inhibitor L-NMMA on basal CBF and vasoneuronal coupling in man: a PET study. J Cereb Blood Flow Metab. 1999;19(6):673-8. doi:10.1097/00004647-199906000-00011

17. Thomas JE, Rosenwasser RH, Armonda RA, Harrop J, Mitchell W, Galaria I. Safety of intrathecal sodium nitroprusside for the treatment and prevention of refractory cerebral vasospasm and ischemia in humans. Stroke 1999;30(7):1409-16. doi:10.1161/01.STR.30.7.1409

18. Kellert L, Rocco A, Sykora M, Hacke W, Ringleb PA. Frequency of increased blood pressure levels during systemic thrombolysis and risk of intracerebral hemorrhage. Stroke. 2011;42(6):1702-6. doi:10.1161/STROKEAHA.110.604744

19. Geeganage C, Tracy M, England T, Sare G, Moulin T, Woimant F et al. Relationship between baseline blood pressure parameters (including mean pressure, pulse pressure, and variability) and early outcome after stroke: data from the Tinzaparin in Acute Ischaemic Stroke Trial (TAIST). Stroke. 2011;42(2):491-3. doi:10.1161/STROKEAHA.110.596163

20. Mattle HP, Kappeler L, Arnold M, Fischer U, Nedeltchev K, Remonda $L$ et al. Blood pressure and vessel recanalization in the first hours after ischemic stroke. Stroke. 2005;36(2):264-8. doi:10.1161/01.STR.0000153052.59113.89 